\title{
WORKING CAPITAL MANAGEMENT AND FIRM VALUE: THE ROLE OF FIRM INNOVATIVENESS
}

\author{
Saheed Nurein ${ }^{1}$ and Salleh Din $^{2}$ \\ ${ }^{1,2}$ School of Business Innovation and Technopreneurship, \\ ${ }^{1,2}$ Universiti Malaysia Perlis, Perlis, Malaysia
}

\begin{abstract}
There have been variations in working capital performance among firms and industries in various countries over the last decade. One of the causes of the variations is level of firm innovativeness. This study aims to examine the moderating role of firm innovativeness on the effect of working capital management on firm value between innovative and non-innovative firms in an emerging market. The study was carried out based on 400 listed firms in Bursa Malaysia for the period 2006-2015. By using a fixed regression estimation, the findings indicate that innovative firms have a better working capital performance than the non-innovative firms since they apply their innovative capabilities towards improving their working capital performance. This study suggests that firms need to align their innovative capabilities towards working capital management to improve firm value.
\end{abstract}

Keywords: Working Capital Management, Firm Value, Firm Innovativeness, Cash Conversion Cycle

\section{Introduction}

Generally, firms may look at the time spent in managing working capital as less vital in compare to other key decisions such as payout decisions or capital budgeting, but aftermath the 2008 global financial crisis, firms realized the significance of managing working capital judiciously (Charitou et al., 2010). This is because the valuable cash tied up through working capital cycle contributes to business failures and played a critical role in firm performance during the financial crisis (Campello et al., 2011, 2012; Campello et al., 2010; Claessens et al., 2000; Pomerleano, 1998). It is then obvious to firms that their liquidity problems can only be solved through effective liquidity and cash management, since an effective way to lessen the reliance on external funding and counter-market difficulties is to continue to track and optimize internal resources (Rydel, 2012).

However, despite the enormous awareness towards working capital management (WCM henceforth) after the financial crisis, survey has shown that the performance of working capital has increasingly deteriorated by $€ 300$ billion over the years globally and worse than the levels before the financial crisis (PWC 2016). According to Ernst and Young global working capital reports (2011 to 2016), approximately US\$1.2 trillion of cash is tied up in working capital of the firms every year since 2011. This represents a large proportion of the scope of their working capital and equals $7 \%$ of their combined sales. It also implies that for every US\$1 billion in sales, working capital could improve averagely by US\$70 million.

Furthermore, various reports on working capital performance (Deloitte, 2012; Ernst \& Young, 2016; The Hackett Group, 2016; KPMG, 2011; PWC, 2016; REL, 2016), also depict variation in working capital performance among firms and industries in various countries over the last decade. While some of the firms are consistently improving yearly in their working capital, some others record deteriorating performance every year which is tying up billions of dollars meant to be used to improve their overall performance. These reports have also traced the causes of this issue of variation to many factors, which they generally accepted that firms' innovativeness is one of the causes of the varied performance. The report of PWC (2012) which specifically focused on what the top performing companies are doing differently to reduce their working capital concluded

Corresponding Author: Saheed Nurein./ saheed_nurein@yahoo.com 
that "The most successful companies are constantly adapting themselves to a new regulatory environment and are innovating by making the most out of technology to achieve significant reductions in working capital" (p.3).

The above conclusion is an indication that those firms that are improving consistently in their working capital performance yearly may involve in significant innovation and make use of their innovative capabilities to improve their working capital performance. A good example is firms that have renewed interest in evaluating possibilities in supply chain finance programmes. This allows them to make the most of accounts payable processing technology and create a win-win situation, because the supplier will get paid within short time frames and the firm benefits from extended payment terms. Meanwhile, those firms that continuously achieving deteriorating performance may involve in insignificant innovation and may not direct their innovative capability towards improving their working capital performance.

This assumption has been identified by Filbeck and Krueger (2005) where they concluded that rate of firm innovation is one of the organizational factors that can impact WCM. Also, Tauringana and Afrifa (2013) corroborated this in their argument that the type of any WCM policy chosen could either increase or decrease the profitability of a firm, depending on the firms innovativeness and availability of resources including expertise, technology, and finance. Therefore, it can be concluded that firms' innovativeness is an internal organizational setting that affect the relationship between WCM and firm value which need empirical investigation. This study aims to empirically examine this assumption by examining the moderating effect of firm innovativeness on the relationship between WCM and firm value.

\section{Literature Review and Hypotheses}

\subsection{Literature Review}

\subsubsection{Working Capital Management and Firm Value}

The knowledge and understanding of the WCM policies among large firms is presently insufficient because payment terms is still generally longer in most countries and regions despite the fact that ineffective WCM and late payment are known as the main basis of business failures (Ernst \& Young, 2015;Tingbani, 2015). Late payments cause an increase in working capital for the firms due to the need to raise financing from one of the four sources (Chittenden \& Bragg 1997). It also increased debt, which resulted into higher interest payments, reduced borrowing capacity, reduced profits, increased equity, which dilutes and devalues existing investors' stakes if stockholders' returns are unaffected; reduced capital investment in the future, limiting the seller's longterm business performance; or an increase in the length (and therefore the amount) of trade credit taken from suppliers (Fisman \& Love, 2003; Love et al,, 2007; Love \& Zaidi, 2010; Paul \& Boden, 2014; Paul et al., 2012; Zainudin, 2008). Late payment is, therefore, an imperative factor that may deter overall firm value.

Though, previous studies (e.g., Aktas et al., 2015; Autukaite \& Molay, 2013; Kieschnick et al., 2013; Wang, 2002; Wasiuzzaman, 2015) have focus on the impact of WCM and its components (i.e. account receivables, account payables and inventory holding) on firm value, however, there is need for more studies to concentrate on large firms due to their vulnerabilities of managing working capital in recent years and because most large firms have a tendency of having a large amount of cash invested in working capital, and considerable amounts of short-term payables, as a basis of financing (Deloof, 2003). Therefore, there is still need for more studies on WCM to focus on large firms, specifically comparative studies of large firms among countries.

In addition, there is inconsistent results among past studies. While some studies found a negative relationship between WCM and firm value (e.g., Aktas et al., 2015; Autukaite \& Molay, 2013; De Almeida \& Eid jr, 2014; Kieschnick et al., 2008; Kieschnick et al., 2013; Lifland, 2011; Mohamad \& Saad, 2010; Wasiuzzaman, 2015), others found a positive relationship (e.g., Abuzayed, 2012; Ali \& Ali, 2012; Lyroudi \& Lazaridis, 2000; Rimo \& Panbunyuen, 2010). Varying explanation has been given by different researchers on the direction of the 
relationship between WCM and firm value. While some studies (e.g., Aktas et al., 2015; Autukaite \& Molay, 2013; De Almeida \& Eid jr, 2014; Lifland, 2011; Wasiuzzaman, 2015) argue that the reduction in WCM increases firm value, other studies (e.g., Abuzayed, 2012; Ali \& Ali, 2012; Lyroudi \& Lazaridis, 2000; Rimo \& Panbunyuen, 2010) also argue that higher working capital increases firm value.

Meanwhile, Abuzayed (2012) argue that the plausible reason for positive relationship is that investors in stock market do not base their firm selection on firms with efficient and effective working capital, and also ignores liquidity as a crucial factor in evaluating firm value. He also stressed that a positive relationship shows that firms that are more profitable are less driven to manage working capital efficiently; the letdown of the financial market to penalize these firms for managing working capital inefficiently leads to such positive relationship. Based on these assertions, there is need for more studies to provide new evidence for these claims and contribute to the contemporary knowledge on the WCM and firm value relationship.

\subsubsection{Firm Innovativeness and Firm Value}

According to Subramanian and Nilakanta (1996) the implicit assumptions of innovation is that it is a firm response to changes in external environment; while the believe of contingency theory proponents is that a firm external environment is incontrollable; for a firm to be successful, its needs to acclimatize to the fluctuating environmental situations by changing its firm characteristics which include its processes or its structure (Lawrence \& Lorsch 1967). Innovativeness denotes the concept of openness to new ideas as a characteristic of firm's culture while capacity to innovate is the ability of the organization to adopt or implement new ideas, processes, or products successfully (Cheng \& Lin, 2012; Jha et al., 2016; Lagat \& Frankwick, 2015; Slaughter, 2015). It is obvious that firms have different levels of innovative capabilities, nonetheless innovative activities need to be focused on many aspects simultaneously such as new products, new organizational and marketing practices or administrative systems, and new process technologies (Camison \& Villar-Lopez, 2014; Huang et al., 2015; Jiménez-Jiménez \& Sanz-Valle, 2011; Walker, et al., 2015).

Moreover, according to Damanpour and Gopalakrishnan (2001), Damanpour and Wischnevsky (2006) and Damanpour and Evan (1984), a balanced rate of adoption of administrative and technical innovations are more effective in aiding firms to preserve and improve their level of performance than implementing them alone. Although innovation literature does not reveal a conclusion whether a specific innovation type is likely to provide more or less an impact on corporate performance, it can be concluded that innovations influence each other and need to be implemented in conjunction (Damanpour \& Wischnevsky 2006). Thus, an innovative firm is one which aims to enhance production or delivery capabilities through improvements in productivity, efficiency or quality, or by facilitating the production of new products. Based on all these arguments, it can be assumed that the effect WCM will have on firm value of innovative firms may be different from that of noninnovative firms. This study aims to empirically examine this assumption by examining the moderating effect of firm innovativeness which will be divided into innovative and non-innovative firms, on the relationship between WCM and firm value.

\section{$1.2 \quad$ Hypotheses Development}

\subsubsection{Working Capital Management and Firm Value}

Cash conversion cycle (CCC) can be regarded as an appendage in evaluating working capital since it implies the numbers of days needed by a firm to finance its current assets with extra funds. It is better for a firm to have a shorter CCC because as costs of financing day-to-day activities reduce then the cash used in providing current assets will return quicker (Gołaś et al., 2012). Thus, through combining the short term operating efficiency and the vital components of a firm's liquidity, CCC can be sustained as WCM main variable. 
Soenen (1993) argued that the duration of the cash conversion cycle (CCC) determines firm value; and firms with shorter duration of CCC attain higher firm value. In addition, firms with shorter duration of CCC can maximize their firm value due to their capability to internally generate funds, which could decrease their reliance on external financing (Autukaite \& Molay, 2013; Baños-Caballero et al., 2014). Studies such as Deloof (2003), Lazaridis and Tryfonidis (2006), García-Teruel and Martínez-Solano (2007), and Baños-Caballero et al. (2014) have evidence of a negative significant relationship between the profitability of the firm and CCC. Deloof (2003) suggested that minimum level of reduction in account receivable days and inventory holding days enhance shareholders' value. Lazaridis and Tryfonidis (2006) also suggested that the more firms delay payments of their payable, the higher the working capital level reserved and used in improving firm value. In addition, the study of García-Teruel and Martínez-Solano (2007) also show that firm profitability is negatively related with both account receivable days and inventory holding days, and suggested that mangers could create value by shortening CCC since it increases the available cash flow used in operating their day-to-day activities. Therefore, this study hypothesized that CCC has relationship with firm value as follows, based on previous studies:

Hla: There is a negative relationship between the cash conversion cycle and firm value.

The components of CCC are accounts receivable days and accounts payable days and inventory holding days. In order to understand the WCM and firm value relationship, there is need to disintegrate the individual components of WCM disjointedly dues to their different consequences on firm value (Afrifa, 2013). Optimizing each of the components can enable a firm to minimize its CCC (Enqvist et al. 2014).

In regards to account receivables, it usually serves as short-term advances to buying firm given by the supplying firm. Accounts receivable policy of a firm always affect its firm value significantly (García-Teruel \& MartínezSolano, 2010). Decrease in number of accounts receivable days improve firm value through increase in available cash flow. This increase in available cash flow will assist firms to meet their short-term obligations, evade cash shortage, take advantage of optimistic speculation and development opportunities, and lessen transactional cost of bills paying as well as cost of financial distress (Petersen \& Rajan, 1997). In line with the arguments, this study assumed that account receivables period has relationship with firm value as follows:

H2a: There is a negative relationship between the account receivables period and firm value.

Based on inventory, it is essential for firms to keep inventory for precaution purposes because of imperfections; and level of inventory held has impact on their firm value (Eroglu \& Hofer, 2011). Reducing level of inventory held increases firm value since the funds untied through the reduction can be invested elsewhere; and it also avoid seeking short-term credit to finance inventory (Deloof, 2003). Therefore, this study assumed the following relationship between inventory holding period and firm value:

H3a: There is a negative relationship between the inventory holding period and firm value.

On the other hand, accounts payable serve as an essential source of short-term funds for many firms. Firms prefer achieving an optimal accounts payable policy because of market imperfection, which could impact firm value (Baños-caballero et al., 2014). Delaying accounts payable assist to enhance operational efficiency as well as firm value through reduction in transactional cost, exchange costs. It also assist firm in accumulating amounts owed and pay them periodically based on the credit period agreement; which then enable them to avoid financial constraint (Bhattacharya, 2008). In consistent with the arguments, it is assumed that account payable periods and firm value are related as follows:

H4a: There is a positive relationship between the accounts payable period and firm value.

\subsubsection{Working Capital Management, Firm Innovativeness and Firm Value}


The direct effect of firm innovativeness on WCM and firm value relationship has not been investigated by any study. However, few studies (e.g., Halkola, 2014; Hofmann \& Kotzab, 2010; Jingmeng, 2013; Li et al., 2014; Lind et al., 2012) have revealed the effect of some aspects of firm innovativeness on WCM and its components. Vuorikari (2012) examined the optimization of WCM from processes viewpoint. The study concluded that WCM can be improved through numerous activities with little determination, though, seeing the effect of the activities is a further study yet to be examined. The study revealed the most essential processes that need reformation, which include invoicing, purchasing, as well as credit management. Faster issuing of invoice and short payment terms decrease the span of receiving payment from customer. Making negotiation on longer payment terms and larger order sizes are vital in the process of purchasing. Also, collecting and inspecting credit rating reduces the risk for bad debts.

Halkola (2014) investigates the improvement of inventory turnover and WCM through business model innovation. The findings imply that the Case company can improve its inventory turnover and WCM by developing a responsive supply chain. In addition, the company could also improve its inventory turnover and WCM by optimizing batch sizes. Hofmann and Kotzab (2010) examine a supply chain-oriented approach to WCM, with the aim of exploring the difference between the cash-to-cash cycle in a single firm and from a supply chain-oriented viewpoint through analyzing the role of payment terms for improving working capital. The conclusion of the study is that effective management of a firm supply chain improve WCM. Also, Lind et al., (2012) examine WCM in the automotive industry using financial value analysis, with the objective of analyzing WCM through the value chain from the raw material suppliers to the end customers. This will make the firm receives a holistic understanding of the value chain it operates in.

Moreover, Li et al. (2014) examine the effect of strategic choice on WCM and performance relationship. The findings indicate that working capital is configured and adjusted to its target in different ways under different competitive strategic choices. This effect is finally transferred to influence the relationship between working capital configuration and operational performance. Jingmeng (2013) also construct a management system based on the modifying cycle of WCM performance. This system includes five basics, which are management goal, management policy, business environment, management performance and management mode. The main purpose of the system is to achieve the long-term improvement of WCM.

However, the effective use and advanced structure of a firm's internal settings formulate its innovativeness. Empirical influence of some innovative aspects of firm internal settings on WCM indicates that firm innovativeness may affect the WCM and firm value relationship. Therefore, this study assumes the following hypotheses:

Hlb: Firm innovativeness moderates the relationship between Cash Conversion Cycle and Firm Value.

H2b: Firm innovativeness moderates the relationship between Accounts Receivable Period and firm value.

H3b: Firm innovativeness moderates the relationship between Accounts Payable Period and firm value.

H4b: Firm innovativeness moderates the relationship between Inventory Holding Period and firm value.

As some studies found evidence of influence of firm innovativeness on firm value, growth, and overall performance (e.g., Domi, 2016; Geldes et al., 2016; Jiménez-Jiménez \& Sanz-Valle, 2011; Lisboa et al., 2011; Ortega, 2010; Rhee et al., 2010; Tsai \& Yang, 2013; Yam et al., 2011; Yang, 2012; Zhang et al., 2013), few studies also found in found insignificant relationship between firm innovativeness and firm performance (e.g., Chandler, Keller, \& Lyon, 2000; Terziovski, 2010). This is an indication that despite that firm innovativeness improves firm performance, there is still inconsistency from the empirical studies (Tsai \& Yang 2013). 
The plausible for this inconsistency could be traced to the level of firm innovativeness. According to Baldwin and Johnson (1995), the level of firm innovativeness could differentiate firms into innovative and noninnovative firms. They argued that innovative firms lay more emphasis on human resources, financing, marketing, production economics, technological advancement, government programs and supports, management, growth than non-innovative firms. In addition, innovative firms usually combine their available resources with their innovative to improve their firm value. Baldwin and Johnson (1995) concluded that innovative firms can also be categorized as more-innovative or more-successful firms, and non-innovative firms as less-innovative or less-successful firms. Therefore, based on this differentiation, this study hypothesizes that:

H5: The working capital management and firm value relationship of Innovative firms are better than the working capital management and firm value relationship of Non-Innovative firms

H6: The effect of firm innovativeness on working capital management and firm value relationship of Innovative firms is better than the effect of firm innovativeness on working capital management and firm value relationship of Non-Innovative firms

\section{Data Environment and Variables Description}

\subsection{Data environment}

The data of 400 non-financial firms listed on the main market of Bursa Malaysia for the period 2006-2015 was used for this study. The firms were divided into innovative and non-innovative firms based on the definition of innovative firms by the Organisation for Economic Co-operation and Development (OECD) (Gehrke \& Grupp, 1994; Grupp, 1995) and the NIW-ISI-list (Lower Saxony Institute for Economic Research (NIW) and Institute for Systems and Innovation Research (ISI)). They separated industries into 'High-Tech Industries' and 'NonHigh Tech Industries' due to their R\&D intensity and differentiation of 'technology intensive' goods. They regarded firms in 'High Tech Industries' as innovative firms and firms in 'Non-High-Tech Industries' as noninnovative firms. Therefore, in consistent with the OECD definition, the innovative firms used for this study are listed in table 1 (below).

Table 1 List of Innovative and Non-Innovative industries and Firms selected for this study

\begin{tabular}{lccc}
\hline Innovative Industries & No of Firms & Non-Innovative Industries & No of Firms \\
\hline Aerospace \& Defense & 1 & Beverages & 6 \\
\hline Automobiles \& Parts & 10 & Construction and Materials & 40 \\
\hline Chemicals & 15 & Food \& Drug retailers & 3 \\
\hline Electronic \& Electrical Equipment & 15 & Food producers & 35 \\
\hline Forestry \& Paper & 15 & Media & 5 \\
\hline General Industrials & 20 & Industrial Transportation & 15 \\
\hline Health Care Equipment \& Services & 7 & Mobile Telecommunications & 5 \\
\hline Household Goods & 20 & Travel \& Leisure & 15 \\
\hline Industrial Engineering & 21 & Personal Goods & 15 \\
\hline Industrial Metals \& Mining & 15 & Real Estate Investments \& Services & 37 \\
\hline Oil \& Gas Producers & 8 & Real Estate Investments Trusts & 8 \\
\hline Oil equipment \& Services & 11 & Support Services & 13 \\
\hline Pharmaceuticals \& Biotechnology & 6 & Fixed Line Telecommunications & 2 \\
\hline Software \& Computer Services & 20 & Tobacco & 1 \\
\hline Technology Hardware & 16 & $\mathbf{2 0 0}$ & Total \\
\hline Total & & & $\mathbf{2 0 0}$ \\
\hline
\end{tabular}




\subsection{Variable measurement}

The dependent variable is firm value and is measured using enterprise value. Enterprise value is generally used in identifying undervalued firms and is a robust market value proxy (Lifland 2011), because it provides the economic measure of real market value of firm as a whole business(Bhullar \& Bhatnagar 2013). Enterprise value put into consideration debt obligations, non-controlling minority interest and excess cash in valuing a firm. Thus, this study used a unique ratio of enterprise value-to-operating performance (EV/EBITDA) as a measure of firm value. This means firm value is enterprise value divided by Earnings before interest, taxes, depreciation and amortization (EV/EBITDA). Enterprise value is measured as Equity Value + Total Debt-Cash \& Cash Equivalents + Preferred Stock + Minority Interest. Previous studies (e.g., Deloof, 2003; García-Teruel \& Martínez-Solano, 2007; Soenen, 1993) have adopted the CCC as the main measure of working capital management. This study also adopts CCC as a proxy for working capital management. CCC measures the time lag between expenditure for the purchase of raw materials and the collection of sales of finished goods; or reveals the time (days) interval needed to convert a dollar invested in current assets into cash (Richards \& Laughlin 1980). Other independent variables are account receivables period, inventory holding period, and account payables period. Moderating variable is firm innovativeness and it is proxied by R\&D Investments. It is measured through dividing R\&D expenditure by total sales volume. Control variables applied are firm size, financial leverage, liquidity ratio, assets tangibility, and firm growth. The measurements for the variables are depicted in table 2 (below).

Table 2 Variables Measurement

\begin{tabular}{|c|c|c|c|}
\hline No & Variables & Connotation & Measurement \\
\hline 1. & Firm Value & $\mathrm{FV}$ & $\begin{array}{l}\text { (Equity Value + Total Debt- Cash \& Cash Equivalents } \\
\text { + Preferred Stock + Minority Interest)/EBITDA }\end{array}$ \\
\hline 2. & Cash conversion cycle & $\mathrm{CCC}$ & $\begin{array}{l}\text { Account receivables period + Inventory holding period - } \\
\text { Account payables period. }(\mathrm{ARP}+\mathrm{IHP}-\mathrm{APP})\end{array}$ \\
\hline 3. & Account receivables period & ARP & $\begin{array}{l}\text { Accounts receivables divided by sales and multiplied by } \\
\qquad 365 \text { days. (AR/Sales) X } 365\end{array}$ \\
\hline 4. & Inventory holding period & IHP & $\begin{array}{l}\text { Inventory divided by cost of sales and multiplied by } 365 \\
\text { days. (INV/COS) X } 365\end{array}$ \\
\hline 5. & Account payables period & APP & $\begin{array}{l}\text { Accounts payables divided by cost of sales and } \\
\text { multiplied by } 365 \text { days. (AP/COS) X } 365\end{array}$ \\
\hline 6. & Firm Innovativeness & R\&D & R\&D expenditure divided by total sales volume \\
\hline 7. & Firm size & SIZE & Natural logarithm of sales \\
\hline 8. & Financial leverage & LEV & Total debt divided by total capital \\
\hline 9. & Liquidity ratio & LIQ & Current assets divided by current liabilities \\
\hline 10. & Assets tangibility & ASTAN & Fixed assets divided by total assets. \\
\hline 11. & Firm growth & GROWTH & (Current sales -previous sales) / previous sales \\
\hline
\end{tabular}

The following models were estimated to examine the hypotheses:

$$
\begin{aligned}
& F V_{\mathrm{it}}=\beta_{o}+\beta_{I} C C C_{i t}+\beta_{2} A R P_{i t}+\beta_{3} A P P_{i t}+\beta_{4} I H P_{i t}+ \\
& \beta_{5} \text { FIRMSIZE }_{i t}+\beta_{6} \text { LIQ }_{i t}+\beta_{7} L E V_{i t}+\beta_{8} \text { ASTAN }_{i t} \\
& +\beta_{9} G R O W T H_{i t}+V_{i t}+\varepsilon_{i t} \\
& F V_{i t}=\beta_{o}+\beta_{1} C C C_{i t}+\beta_{2} A R P_{i t}+\beta_{3} A P P_{i t}+\beta_{4} I N V_{i t}+ \\
& \beta_{5} \text { FIRMSIZE }_{i t}+\beta_{6} \text { LIQ }_{i t}+\beta_{7} L E V_{i t}+\beta_{8} A_{S T A N}
\end{aligned}
$$




$$
+\beta_{10} G R O W T H_{i t}+\beta_{11} R \& D^{*} C C C_{i t}+\beta_{12} R \& D^{*} A R P_{i t}+\beta_{13} R \& D^{*} A P P_{i t}+\beta_{14} R \& D^{*} I H P_{i t}+V_{i t}+\varepsilon_{i t}
$$

$$
\begin{aligned}
& F V_{\mathrm{it}}=\beta_{o}+\beta_{1} C C C_{i t}+\beta_{2} A R P_{i t}+\beta_{3} A P P_{i t}+\beta_{4} I H P_{i t}+ \\
& \beta_{5} \text { FIRMSIZE }_{i t}+\beta_{7} L I Q_{i t}+\beta_{8} L E V_{i t}+\beta_{9} A_{S T A N} \\
& +\beta_{10} \text { GROWTH }_{i t}+\beta_{11} \mathrm{COMP}_{i t}+V_{i t}+\varepsilon_{i t} \quad \text { (3) } \\
& F V_{\mathrm{it}}=\beta_{o}+\beta_{1} C C C_{i t}+\beta_{2} A R_{i t}+\beta_{3} A P_{i t}+\beta_{4} I N V_{i t}+ \\
& \beta_{5} \text { FIRMSIZE }_{i t}+\beta_{6} \text { BSIZE }_{i t}+\beta_{7} L I Q_{i t}+\beta_{8} L E V_{i t} \\
& +\beta_{9} \text { ASTAN }_{i t}+\beta_{10} \text { GROWTH }_{i t}+\beta_{11} R \& D^{*} C C C_{i t} \\
& +\beta_{12} R \& D^{*} A R_{i t}+\beta_{13} R \& D^{*} A P_{i t}+\beta_{14} R \& D^{*} I N V_{i t} \\
& +\beta_{15} C O M P_{i t}+V_{i t}+\varepsilon_{i t}
\end{aligned}
$$

Where: FV $=$ Firm Value, $\mathrm{CCC}=$ Cash Conversion Cycle, ARP $=$ Account Receivables Period, APP $=$ Account Payables Period, INV = Inventory Holding Period, FIRMSIZE $=$ Firm Size, LIQ $=$ Liquidity Ratio, LEV = Financial Leverage, ASTAN $=$ Asset Tangibility, GROWTH $=$ Firm Growth, R\&D= Firm Innovativeness, $\mathrm{COMP}=$ Comparative dummy variable, $\mathrm{V}_{\mathrm{it}}=$ Unobserved company effects (fixed effects), $\varepsilon_{\mathrm{it}}=$ idiosyncratic shocks $\mathrm{i}=$ nth firm, $\mathrm{t}^{\text {th }}=\mathrm{t}^{\text {th }}$ year

The first equation (1) specifies a direct relationship between working capital management and firm value without the moderating variable which is to examine hypotheses H1a to H4a, while the second equation (2) indicates the relationship with the consideration of the moderating variable. Thus, correlation and OLS fixed effect estimation was applied to examine the models.

\section{Analysis and Findings}

\subsection{Summary Statistics}

The summary of descriptive statistics of the variables are shown in table 3 (below).

Table 3 Descriptive statistics

\begin{tabular}{llllllll}
\hline Variable & Obs. & Mean & Std Dev. & Min & Max & Skewness & Kurtosis \\
& & & & & & & \\
FV & 4000 & 1.018647 & 0.536542 & 0.925416 & 1.653815 & 1.241412 & 2.332672 \\
\hline CCC & 4000 & 125.4286 & 183.7103 & -1242.64 & 7210.31 & 8.25494 & 10.67531 \\
& & & & & & & \\
\hline ARP & 4000 & 95.63246 & 50.41816 & -738.3242 & 867.4923 & 4.736820 & 12.74637 \\
& & & & & & & \\
\hline IHP & 4000 & 101.2457 & 124.3652 & -0.952742 & 943.1371 & 5.356494 & 11.51423 \\
& & & & & & & \\
\hline APP & 4000 & 94.216 & 143.6892 & -837.5482 & 964.2364 & 3.485326 & 10.67553 \\
\hline R\&D & 4000 & 7.892134 & 12.28656 & -98.6 & 89.46 & -0.075981 & 15.61462 \\
\hline FIRMSIZE & 4000 & 4.56047 & 1.53412 & -1.572241 & 6.421835 & -1.356434 & 6.457372 \\
\hline LEV & 4000 & 0.6859837 & 8.11396 & -0.865981 & 261.2188 & 26.11288 & 871.9942 \\
\hline LIQ & 4000 & 1.953286 & 2.463738 & 0 & 92 & 14.43428 & 862.1354 \\
\hline ASTAN & 4000 & 7.465265 & 76.78566 & -1.744256 & 784.7459 & 12.63168 & 146.3482 \\
\hline
\end{tabular}




\begin{tabular}{llllllll}
\hline GROWTH & 4000 & 0.8342134 & 8.532284 & -42.49936 & 289.7183 & 27.62864 & 924.2658
\end{tabular}

Firm value shows approximately an average of $102 \%$, which indicates that the firm value of the firms is very robust for these periods studied. CCC shows an average of 125 days, account receivables period with average of 95days, inventory holding period with 101 days averagely, and account payable period with an average of 94 days. This is an indication that it took averagely longer days for the firms to convert their sales to cash during the periods examined. $R \& D$ investments shows an average of $78.9 \%$, which implies that there is high $R \& D$ investment in ratio to total sales during these periods investigated.

\subsection{Correlation Matrix}

Table 4 Correlation result of the variables

\begin{tabular}{llllllllllll}
\hline Variable & FV & CCC & ARP & INV & APP & R\&D & SIZE & LEV & LIQ & ASTAN & GROWTH \\
\hline FV & 1.00 & & & & & & & & & & \\
\hline CCC & - & 1.00 & & & & & & & & & \\
& $.05^{* * *}$ & & & & & & & & & & \\
\hline ARP & - & $.18^{* * *}$ & 1.00 & & & & & & & \\
& $.12^{* * *}$ & & & & & & & & & \\
\hline INV & $.07^{* * *}$ & $.38^{* * *}$ & $.04^{* *}$ & 1.00 & & & & & & \\
\hline APP & $-.03^{* *}$ & $.64^{* * *}$ & $.03^{* *}$ & $.05^{* *}$ & 1.00 & & & & & \\
\hline R\&D & $.16^{* * *}$ & $-.08^{* *}$ & $.05^{* *}$ & $.04^{* *}$ & $.07^{*}$ & 1.00 & & & & \\
\hline SIZE & $.50^{* * *}$ & $-.07^{* *}$ & - & $.02^{*}$ & $.01^{* *}$ & - & 1.00 & & & \\
& & & $.04^{* *}$ & & & $.04^{* *}$ & & & & \\
\hline LEV & -.04 & -.02 & - & $.05^{*}$ & $.03^{* *}$ & -.10 & - & 1.00 & & & \\
& & & $.08^{* *}$ & & & & $.04^{* *}$ & & & & \\
\hline LIQ & - & $.10^{* *}$ & $.06^{* *}$ & $.04^{* *}$ & $.06^{* *}$ & $.02^{* *}$ & $.05^{*}$ & $-.08^{*}$ & 1.00 & & \\
& $.20^{* * *}$ & & & & & & & & & & \\
\hline ASTAN & $.04^{* * *}$ & $.05^{* *}$ & $.30^{* *}$ & $.04^{* *}$ & $.07^{*}$ & $.05^{* *}$ & $.04^{* *}$ & $.03^{* *}$ & $.02^{*}$ & 1.00 & \\
\hline GROWTH & $.06^{* * *}$ & $.07^{* *}$ & $.05^{*}$ & $-.03^{*}$ & $.05^{* *}$ & $.04^{* *}$ & $.05^{* *}$ & .02 & $.01 *$ & .03 & 1.00 \\
\hline
\end{tabular}

Significance levels are at $1 \%(* * *), 5 \%(* *)$ and $10 \%(*)$

A Pearson correlation analysis was applied to measure the extent of linear relationship that exist between the variables used in this study, which is depicted in Table 4 (above). Also, a variance inflation factor was used to test the present of multicollinearity The test show that the largest VIF is 1.462 (LEV), approving the absent of multicollinearity in the sample since the highest VIF is below 10 (Hair et al., 2006). Furthermore, the coefficients of the variables are less than the limit of 0.87 or 0.97 as in line with Field (2009). The results show that firm value and CCC are negatively correlated, indicating that reduction in working capital level will increase firm value because firms can convert their inventories into sales within short periods, receive cash from their credit sales and delay their payables. Account receivable period and firm value are negatively correlated, which implies that firm value is negatively influenced by the account receivable policy of the firms. As inventory and firm value indicates a negative correlation, it implies that firm value is negatively affected by the firm's inventory policy. Account payable period and firm value shows a positive relationship, which implies that firm value was increased by longer payable period.

\subsection{Regression Results}

Table 4 Fixed Effects regression of the models

\begin{tabular}{|c|c|c|c|c|c|c|}
\hline & \multicolumn{2}{|c|}{ All Selected Firms } & \multicolumn{2}{|c|}{ Innovative Firms } & \multicolumn{2}{|c|}{ Non-Innovative Firms } \\
\hline & Model 1 & Model 2 & Model 3 & Model 4 & Model 5 & Model 6 \\
\hline $\mathrm{CCC}$ & $-0.369 * * *$ & $-0.593 * * *$ & $-0.470 * * *$ & $-0.647 * * *$ & $-0.281 * * *$ & $-0.496 * * *$ \\
\hline
\end{tabular}




\begin{tabular}{|c|c|c|c|c|c|c|}
\hline & $(-3.12)$ & $(-5.47)$ & $(-4.31)$ & $(-6.36)$ & $(-3.22)$ & $(-4.71)$ \\
\hline ARP & $\begin{array}{l}-0.499 * * * \\
(-6.71)\end{array}$ & $\begin{array}{l}-0.553 * * * \\
(-8.41)\end{array}$ & $\begin{array}{l}-0.316^{* * * *} \\
(-5.63)\end{array}$ & $\begin{array}{l}-0.426 * * * \\
(-7.25)\end{array}$ & $\begin{array}{l}-0.298 * * * \\
(-5.18)\end{array}$ & $\begin{array}{l}-0.356 * * * \\
(-6.43)\end{array}$ \\
\hline IHP & $\begin{array}{l}-0.043 * * * \\
(-0.98) \\
\end{array}$ & $\begin{array}{l}-0.534 * * * \\
(-6.38) \\
\end{array}$ & $\begin{array}{l}-0.033 * * * \\
(-0.72) \\
\end{array}$ & $\begin{array}{l}-0.311 * * * \\
(-5.62) \\
\end{array}$ & $\begin{array}{l}-0.029 * * * \\
(-0.81) \\
\end{array}$ & $\begin{array}{l}-0.245 * * * \\
(-4.74) \\
\end{array}$ \\
\hline APP & $\begin{array}{l}0.067 * * * \\
-4.37\end{array}$ & $\begin{array}{l}0.073 * * * \\
-6.14\end{array}$ & $\begin{array}{l}0.082 * * * \\
-3.63\end{array}$ & $\begin{array}{l}0.086^{* * * *} \\
-5.32\end{array}$ & $\begin{array}{l}0.074 * * * \\
-3.26\end{array}$ & $\begin{array}{l}0.082 * * * \\
-4.22\end{array}$ \\
\hline $\mathrm{CCC} * \mathrm{R} \& \mathrm{D}$ & & $\begin{array}{l}0.613 * * * \\
-8.25 \\
\end{array}$ & & $\begin{array}{l}0.742 * * * \\
-9.16\end{array}$ & & $\begin{array}{l}0.624 * * * \\
-8.51 \\
\end{array}$ \\
\hline $\mathrm{ARP} * \mathrm{R} \& \mathrm{D}$ & & $\begin{array}{l}0.657 * * * \\
-5.51\end{array}$ & & $\begin{array}{l}0.765 * * * \\
-7.62\end{array}$ & & $\begin{array}{l}0.675^{* * *} \\
-6.57 \\
\end{array}$ \\
\hline $\mathrm{IHP} * \mathrm{R} \& \mathrm{D}$ & & $\begin{array}{l}0.751 * * * \\
-6.83\end{array}$ & & $\begin{array}{l}0.876^{* * * *} \\
-8.62\end{array}$ & & $\begin{array}{l}0.788^{* * * *} \\
-7.36\end{array}$ \\
\hline APP*R\&D & & $\begin{array}{l}0.662^{* * *} \\
-5.26 \\
\end{array}$ & & $\begin{array}{l}0.871^{* * *} \\
-6.74 \\
\end{array}$ & & $\begin{array}{l}0.718 * * \\
-4.46 \\
\end{array}$ \\
\hline SIZE & $\begin{array}{l}-0.468 * * * \\
(-5.76)\end{array}$ & $\begin{array}{l}-0.492 * * * \\
(-4.27)\end{array}$ & $\begin{array}{l}-0.251 * * * \\
(-4.42) \\
\end{array}$ & $\begin{array}{l}-0.317 * * * \\
(-3.16)\end{array}$ & $\begin{array}{l}-0.356^{* * * *} \\
(-5.21) \\
\end{array}$ & $\begin{array}{l}-0.382 * * * \\
(-4.74)\end{array}$ \\
\hline LEV & $\begin{array}{l}-0.014 * * \\
-3.93 \\
\end{array}$ & $\begin{array}{l}-0.031 * * \\
-4.71\end{array}$ & $\begin{array}{l}-0.011 \text { ** } \\
-2.28\end{array}$ & $\begin{array}{l}-0.019 * * \\
-3.72 \\
\end{array}$ & $\begin{array}{l}-0.012 * * \\
-3.53 \\
\end{array}$ & $\begin{array}{l}-0.024 * * \\
-4.5\end{array}$ \\
\hline LIQ & $\begin{array}{l}-0.041 * * * \\
(-3.22) \\
\end{array}$ & $\begin{array}{l}-0.088^{* * * *} \\
(-5.82) \\
\end{array}$ & $\begin{array}{l}-0.032 * * * \\
(-2.12) \\
\end{array}$ & $\begin{array}{l}-0.054 * * * \\
(-4.61) \\
\end{array}$ & $\begin{array}{l}-0.040^{* * * *} \\
(-2.78) \\
\end{array}$ & $\begin{array}{l}-0.062 * * * * \\
(-5.22) \\
\end{array}$ \\
\hline ASTAN & $\begin{array}{l}-0.024 * * * \\
(-5.28)\end{array}$ & $\begin{array}{l}-0.035^{* * *} \\
(-4.72)\end{array}$ & $\begin{array}{l}-0.020 * * * \\
(-4.94)\end{array}$ & $\begin{array}{l}-0.027 * * * \\
(-3.18)\end{array}$ & $\begin{array}{l}-0.023 * * * \\
(-5.02)\end{array}$ & $\begin{array}{l}-0.012 * * * \\
(-3.29)\end{array}$ \\
\hline GROWTH & $\begin{array}{l}0.009^{* *} \\
-1.56 \\
\end{array}$ & $\begin{array}{l}0.007 \text { ** } \\
-1.25 \\
\end{array}$ & $\begin{array}{l}0.006^{* * *} \\
-1.45 \\
\end{array}$ & $\begin{array}{l}0.004 * * \\
-1.62 \\
\end{array}$ & $\begin{array}{l}0.007 \text { ** } \\
-1.53 \\
\end{array}$ & $\begin{array}{l}0.005^{* *} \\
-1.74 \\
\end{array}$ \\
\hline Constant & & $\begin{array}{l}-8.327 * * * \\
(-18.81) \\
\end{array}$ & & $\begin{array}{l}-4.238 * * * \\
(-14.97) \\
\end{array}$ & & $\begin{array}{l}-6.162 * * * \\
(-16.68) \\
\end{array}$ \\
\hline $\mathrm{R} \& \mathrm{D}$ & & $\begin{array}{l}-0.022 * * \\
(-4.86) \\
\end{array}$ & & $\begin{array}{l}-0.027 * * \\
(-2.53) \\
\end{array}$ & & $\begin{array}{l}-0.027 * * \\
(-3.64) \\
\end{array}$ \\
\hline Observations & 4000 & 4000 & 200 & 200 & 200 & 200 \\
\hline R-SQ & 42 & 65 & 41 & 58 & 43 & 52 \\
\hline Akaike Test & 8463 & 6831 & 6491 & 5214 & 7129 & 6369 \\
\hline Total Effect & & 0.623 & & 0.482 & & 0.401 \\
\hline
\end{tabular}

Significance levels are at $1 \%(* * *), 5 \%(* *)$ and $10 \%(*)$

The results of the fixed regression analysis of the models is depicted in table 4. Model 1 presents the regression on the direct relationship between WCM and firm value. Model 2 presents the regression on the moderating effect of firm innovativeness on the relationship between WCM and firm value. Model 3 and 4 show the regression results for innovative firms, while model 5 and 6 show the results for non-innovative firms.

Model 1 shows a negative relationship between CCC and firm value at $1 \%$ significant level. (at $\mathrm{b}=-0.369$, $\mathrm{p}<0.01)$. Hence, $\mathrm{H} 1 \mathrm{a}$ is accepted, which indicates that with $1 \%$ decrease in $\mathrm{CCC}$ the firm value will increase by $36.9 \%$. This results is in line with the study of Deloof (2003) and Shin and Soenen (1998). Account receivable period and firm value are negatively related at $1 \%$ significant level. (at $b=-0.499, p<0.01$ ). Thus, H2a is accepted, and suggests that the firm value will increase by $49.9 \%$ when account receivable period decrease by $1 \%$. This is consistent with the argument that a shorter account receivable period untied cash and improve firm value (García-Teruel \& Martínez-Solano, 2010; Padachi, 2006). Inventory holding period and firm value are negatively related at $1 \%$ significant level. (at $\mathrm{b}=-0.043, \mathrm{p}<0.01$ ). Therefore, H3a is accepted, and implying that with $1 \%$ decrease in inventory holding period the firm value will rise by $4.3 \%$. It also implies that decreasing inventory through converting it into sales within shorter period increases firm value. This finding is supported by Gill et al. (2010) and Nobanee et al. (2011). Account payable period and firm value are positively related at $1 \%$ significant level. (at $\mathrm{b}=0.067, \mathrm{p}<0.01$ ). Hence, $\mathrm{H} 4 \mathrm{a}$ is accepted, and indicates that at $1 \%$ increase in account 
payable period the firm value increases by $6.7 \%$. This also suggests that delaying payables will increase firm value. The result is in line with the findings of Mathuva (2010) and García-Teruel \& Martínez-Solano (2010b)

Model 2 signifies that the direct relationship between firm value and all the independent variables are still significant and improved than in model 1 . With the presence of the moderating variables, $1 \%$ decrease in $\mathrm{CCC}$, account receivable period and inventory holding period will increase firm value by $59.3 \%, 55.3 \%$ and $53.4 \%$ respectively. Also, at $1 \%$ increase in accounts payable period, firm value will increase by $7.3 \%$. These findings indicate that firm innovativeness affect the relationship between working capital management and firm value positively. Therefore, hypotheses $1 \mathrm{~b}, 2 \mathrm{~b}, 3 \mathrm{~b}$, and $4 \mathrm{~b}$ are accepted. Meanwhile, CCC and the interaction of the firm innovativeness $\left(C C C^{*} R \& D\right)$ is significant and has a positive coefficient $(b=0.613, p<0.01)$. Accounts receivable period and the interaction of firm innovativeness (ARP*R\&D) is significant and has a positive coefficient $(b=0.657, \mathrm{p}<0.01)$. Inventory holding period and the interaction of firm innovativeness $(\mathrm{IHP} * \mathrm{CRN})$ is significant and has a positive coefficient $(b=0.751, \mathrm{p}<0.01)$. Accounts payable period and the interaction of firm innovativeness $(A R P * R \& D)$ is significant and has a positive coefficient $(b=0.662, p<0.01)$. The combine total effect is also significant and positive $(b=0.623, p<0.0)$. This suggests that the interaction of firm innovativeness with working capital management variables improve firm value as anticipated by various reports and studies (e.g., Filbeck \& Krueger, 2005; PWC, 2012).

Furthermore, in regards to the control variables, firm size and firm value are negatively related at $1 \%$ significant level (model $1, b=-0.468 p<0.01$ ), and the direction of the relationship remain the same with the presence of moderating variable in model 2 but with an improve coefficient $(b=-0.492 p<0.01)$. This shows that there is a negative relationship between firm size and firm value; and implies that larger firms generate more profit than smaller firms since larger firms take advantage of economies of scale to improve their return on assets (Bhattacharya, 2014). Based on financial leverage, the result shows a negative relationship between financial leverage and firm value at $5 \%$ significant level (model $1, \mathrm{~b}=-0.014 \mathrm{p}<0.05$ ), and the inclusion of moderating variable in model 2 does not change the relationship but improve the coefficient $(b=-0.031 p<0.05)$. This implies that low leverage firms achieved higher firm value. Likewise, liquidity ratio and firm value are negatively related at $1 \%$ significant level (model $1, b=-0.041 \mathrm{p}<0.01$ ) and the direction remain the same with the moderating effect in model 2 but improved the coefficient $(b=-0.088 p<0.01)$. This is in line with the argument of Hvide and Moen (2007) that decrease in liquidity improves firm value. In addition, assets tangibility and firm value have a negative relationship at $1 \%$ significant level (model $1, b=0.024 p<0.01$ ) and the direction is unchanged with a moderating effect in model 2, but with an improved coefficient $(b=-0.035 \mathrm{p}<$ 0.01). This indicates that any increase in the level of tangible fixed assets will reduce firm value (Raheman \& Nasr 2007). Moreover, firm growth and firm value are positively related at $5 \%$ significant level (model $1, \mathrm{~b}=$ $0.009 \mathrm{p}<0.05)$, and an improved coefficient with moderating effect in model $2(\mathrm{~b}=0.007 \mathrm{p}<0.05)$. This suggests that firms with higher firm growth achieve higher firm value because of they generate higher sales (Hawawini et al., 2003; Serrasqueiro \& Nunes, 2008).

In comparing innovative and non-innovative firms, the results of model 3 shows the relationship between WCM and firm value of innovative firms, while model 4 shows the moderating effect of firm innovativeness on the relationship between WCM and firm value of innovative firms. On the other hand, model 5 shows the relationship between WCM and firm value of non-innovative firms, while model 6 shows the moderating effect of firm innovativeness on the relationship between WCM and firm value of non-innovative firms.

Therefore, comparing the results of model 3 and 5, they both indicate that WCM and firm value are negatively related, and that WCM influence firm value of both innovative and non-innovative firms. However, the influence of WCM on firm value is more robust among innovative firms compare to non-innovative firms. This can be deduced from the coefficient of CCC of innovative firms $(b=-0.470, p<0.01)$ which indicates that at $1 \%$ decrease in CCC of innovative firms their firm value increase by $47 \%$, while coefficient of non-innovative firms $(b=-0.281, p<0.01)$ indicates that at $1 \%$ decrease in CCC the firm value of non-innovative firms will increase 
by $28.1 \%$. Similarly, the influence of each components of WCM (i.e., account receivable period, inventory holding period, and account payable period) on firm value is stronger on innovative firms compare to on noninnovative firms. As $1 \%$ decrease in account receivable period will increase the firm value of innovative firms increase by $31.6 \%(b=-0.316 p<0.01)$, the account receivable period of non-innovative firm will increase by $29.8 \%(b=-0.298 p<0.01)$. This is an indication that account receivable period is tying up more cash in noninnovative firms than in innovative firms. The firm value of innovative firms improves by $3.3 \%$ when inventory holding period decrease by $1 \%(b=-0.033 \mathrm{p}<0.01)$, however, the firm value of non-innovative firms improves by $2.9 \%$ when inventory holding period decrease by $1 \%(b=-0.029 p<0.01)$. This implies that it takes shorter time for innovative firms to convert inventory into sales in compare to non-innovative firms. Also, when account payable period of innovative firms increases by $1 \%$ their firm value increase by $8.2 \%(b=-0.082 p<$ 0.01 ), but when account payable of non-innovative firm increases by $1 \%$ their firm value increases by $7.4 \%(b=$ $-0.074 p<0.01)$. This implies that innovative firms delay their account payable much longer than the innovative firms to increase their firm value.

With the inclusion of moderating effect in model 4 and 6 , the results show that firm innovativeness moderates the relationship between WCM and firm value of both innovative and non-innovative firms. Though, the moderating effect of firm innovativeness on WCM and firm value relationship is more sturdy on innovative firms than on non-innovative firms. The with the presence of firm innovativeness as a moderator, the coefficient of CCC of innovative firms improve and indicates that $1 \%$ reduction in CCC will increase firm value by $64.7 \%$ $(b=-0.647, p<0.01)$, which is higher than $47 \%$ without moderating effect of firm innovativeness. However, for non-innovative firms, the presence of firm innovativeness as a moderator will increase firm value by $49.6 \%$ ( $b=$ $-0.496, \mathrm{p}<0.01$ ) when CCC decreases by $1 \%$, which is higher than $28.1 \%$ without moderating effect of firm innovativeness. This is an indication that rate of firm innovation affect WCM, which then led to improve in firm value (Filbeck \& Krueger 2005). Also, there is plausible reason that innovative firms involve more in innovation through getting the best out of their available resources and innovative capabilities to achieve significant decrease in their working capital, which then improve their firm value (PWC 2012). Meanwhile, non-innovative firms may involve in insignificant innovation and do not direct their innovative capabilities toward improving their WCM, which then reduces their firm value.

\section{Conclusion}

This study is unique in working capital studies as it examines the moderating effect of firm innovativeness on the relationship between working capital management and firm value of selected innovative and non-innovative firms listed in Bursa Malaysia. In consistence with previous studies (e.g., Autukaite \& Molay, 2013; Kieschnick et al., 2008; Wasiuzzaman, 2015), the findings indicate a negative significant relationship between working capital management and firm value. This implies that a decrease in working capital management will increase firm value. This study also show that the presence of firm innovativeness as a moderator between working capital management and firm value significantly improve the relationship. This can be deduced as $1 \%$ decrease in CCC improve firm value by $36.9 \%$ without a moderator and by $59.3 \%$ with moderating effect of firm innovativeness. This study also provide evidence that innovative firms have a better working capital performance than non-innovative firms. This implies that innovative firms improve their working capital by aligning their available resources and their innovative capabilities towards improving their working capital, which then led to increase in their firm value. However, non-innovative firms involve in less innovation, and could not align their available resources and innovative capabilities towards their working capital.

Firms that react to intense competition through investing in R\&D that focus on innovating its products, processes and technology will achieve an improvement in their firm value. This is because firm unique or innovative products, processes and technology create superiority and contribute to firm value (Demsetz, 1973). Firms that align its assets with the changes in environment, the available resources and management capability will improve its firm value. 
This study implies that firm innovativeness influence the management of working capital to improve firm value. This suggests that firms must align their innovative capabilities towards their working capital to improve firm value. The clear reason is that attaining an efficient working capital management does not involve only financial view but also include other disciplines (Baltes, 2015). This led to the argument that to maximize firm value there is need integrate working capital management with business processes since working capital management covers the full choices of business processes (Leavell, 2006). Also, it is essential for firms to make reliable decisions policies that align with their resources to take advantage of opportunities and challenge threats that exist in the environment to improve their firm value.

As this study uses firm innovativeness as dynamic capability that improve the relationship between working capital management and firm value, there are other dynamic capabilities, intangible resources, or innovative capabilities that can improve working capital management and firm value. This study recommends that further research should put into consideration the effect of any of these resource factors on working capital management on firm value.

\section{Reference}

Abuzayed, B., 2012. Working capital management and firms' performance in emerging markets: the case of Jordan. International Journal of Managerial Finance, 8(2), pp.155-179.

Afrifa, G., 2013. Working Capital Management Practices of UK SMEs: The Role of Education and Experience. International Journal of Academic Research in Accounting, Finance \& Management Sciences, 3(4), pp.185-196.

Aktas, N., Croci, E. \& Petmezas, D., 2015. Is working capital management value-enhancing ? Evidence from firm performance and investments. Journal of Corporate Finance, 30, pp.1-55.

Ali, A. \& Ali, S.A., 2012. Working Capital Management: Is It Really Affects the Profitability? Evidence from Pakistan. Global Journal of Business \& Management ..., 12(17), pp.75-78.

De Almeida, J.R. \& Eid jr, W., 2014. Access to finance, working capital management and company value: Evidences from Brazilian companies listed on BM \& FBOVESPA. Journal of Business Research, 67(5), pp.924-934.

Autukaite, R. \& Molay, E., 2013. Cash Holdings, Working Capital and Firm Value : Evidence From France. In 28th International Conference of French Finance Association, Montpellier. pp. 1-22.

Baltes, G., 2015. New perspectives on supply and distribution chain financing: case studies from China and Europe,

Baños-caballero, S., García-teruel, P.J. \& Martínez-solano, P., 2014. Working capital management , corporate performance, and financial constraints. Journal of Business Research, 67(3), pp.332-338.

Bhattacharya, M., 2014. Business growth, size and age: Evidence from the business longitudinal survey (BLS) data in Australia. Australian Economic Papers, 53(3-4), pp.129-138.

Bhullar, P.S. \& Bhatnagar, D., 2013. Theoretical framework EV vs Stock price - A better measurement of firm value. Internation Journal of Commerce, Business and Management, 2(6), pp.335-343.

Camison, C. \& Villar-Lopez, A., 2014. Organizational innovation as an enabler of technological innovation capabilities and firm performance. Journal of Business Research, 67(1), pp.2891-2902.

Campello, M. et al., 2012. Access to liquidity and corporate investment in Europe during the financial crisis. Review of Finance, 16(2), pp.323-346.

Campello, M. et al., 2011. Liquidity management and corporate investment during a financial crisis. Review of 
Financial Studies, 24(6), pp.1944-1979.

Campello, M., Graham, J.R. \& Harvey, C.R., 2010. The real effects of financial constraints: Evidence from a financial crisis. Journal of Financial Economics, 97(3), pp.470-487.

Chandler, G.N., Keller, C. \& Lyon, D.W., 2000. Unraveling the determinants and consequences of an innovation-supportive organizational culture. Entrepreneurship: Theory and Practice, 25(1), 59-59, 25(1), pp.59-59.

Charitou, M.S., Elfani, M. \& Lois, P., 2010. The Effect Of Working Capital Management On Firm's Profitability: Empirical Evidence From An Emerging Market. Journal of Business \& Economic Research, 8(12), pp.63-68.

Cheng, Y. \& Lin, Y., 2012. Performance Evaluation of Technological Innovation Capabilities In Uncertainty. International Conference on Asia Pacific Business Innovation \& Technology Management, 40, pp.287314.

Chittenden, F. \& Bragg, R., 1997. Trade Credit, Cash-flow and SMEs in the UK, Germany and France. International Small Business Journal, 16(1), pp.22-35.

Claessens, S., Djankov, S. \& Xu, L.C., 2000. East Asian Corporations, Before and During the Recent Financial Crisis. World Bank Research Observer, 15(1)(February), pp.23-46.

Damanpour, F. Gopalakrishnan, S., 2001. The dynamics of the adoption of product and process innovations in organizations. Journal of Management Studies 38, 45-65., 38, pp.45-65.

Damanpour, F. \& Wischnevsky, J.D., 2006. Research on innovation in organizations: Distinguishing innovation-generating from innovation-adopting organizations. Journal of Engineering and Technology Management - JET-M, 23, pp.269-291.

Deloitte, 2012. Deloitte 2012 Working Capital Performance Study,

Deloof, M., 2003. Does Working Capital Management Affect Profitability of Belgian Firms? Journal of Business Finance \& Accounting, 30(3-4), pp.573-588.

Demsetz, H., 1973. Industry Structure , Market Rivalry , and Public Policy. Journal of Law and Economics , Published by: The University of Chicago Press, 16(1), pp.1-9.

Domi, S., 2016. Individual and joint effects of innovation, customer orientation and human resources practices on the performance of Albanian tourism SMEs.

Enqvist, J., Graham, M. \& Nikkinen, J., 2014. The impact of working capital management on firm profitability in different business cycles: Evidence from Finland. Research in International Business and Finance, 32, pp.36-49.

Ernst \& Young, 2016. All tied up. Working capital management report,

Ernst \& Young, 2015. All tied up. Working Capital report,

Eroglu, C. \& Hofer, C., 2011. Inventory types and firm performance: Vector autoregressive and vector error correction models. Journal of Business Logistics, 32(3), pp.227-239.

Field, A., 2009. Discovering Statistics Using SPSS. SAGE Publications.

Filbeck, G. \& Krueger, T.M., 2005. An Analysis of Working Capital Management Results Across Industries. American Journal of Business, 20(2), pp.11-20.

Fisman, R. \& Love, I., 2003. Trade Credit , Financial Intermediary and Industry Growth Development ,. The Journal of Finance, 58(1), pp.353-374. 
García-Teruel, P.J. \& Martínez-Solano, P., 2010a. A dynamic approach to accounts receivable: A study of spanish SMEs. European Financial Management, 16(3), pp.400-421.

García-Teruel, P.J. \& Martínez-Solano, P., 2010b. A dynamic perspective on the determinants of accounts payable. Review of Quantitative Finance and Accounting, 34(4), pp.439-457.

García-Teruel, P.J. \& Martínez-Solano, P., 2007. Effects of working capital management on SME profitability. International Journal of Managerial Finance, 3(2), pp.164-177.

Gehrke, B. \& Grupp, H., 1994. Innovationspotential und Hochtechnologie, Technologische Position Deutschlands im internationalen Wettbewerb. Schriftenreihe des Fraunhofer-Instituts fuer Systemtechnik und Innovationsforschung (ISI), Hannover.

Geldes, C., Felzensztein, C. \& Palacios-Fenech, J., 2016. Technological and non-technological innovations, performance and propensity to innovate across industries: The case of an emerging economy. Industrial Marketing Management.

Gill, A., Biger, N. \& Mathur, N., 2010. The Relationship Between Working Capital Management And Profitability : Evidence From The United States. Business and Economics Journal, 2010, pp.1-9.

Group, T.H., 2016. 2016 US Working Capital Survey,

Grupp, H., 1995. Science, High-Technology and the Competitiveness of EU Countries. Cambridge Journal of Economics, 19(October 1993), pp.209-223.

Hair, J.F. et al., 2006. Multivariate data analysis,

Halkola, T., 2014. Improving Inventory Turnover and Working Capital Management by Business Model Innovation.

Hawawini, G., Subramanian, V. \& Verdin, P., 2003. Is performance driven by industry - or firm-specific factors? A new look at the evidence. Strategic Management Journal, 24(1), pp.1-16.

Hofmann, E. \& Kotzab, H., 2010. A Supply chain oriented approach of working capital. Journal of business logistics, 31(2), pp.305-330.

Huang, K.-E. et al., 2015. Innovation and technology creation effects on organizational performance. Journal of Business Research.

Hvide, H. \& Moen, J., 2007. Liquidity constraints and entrepreneurial performance.

Jha, A.K., Bose, I. \& Ngai, E.W.T., 2016. Platform based innovation: The case of Bosch India. International Journal of Production Economics, 171, pp.250-265.

Jiménez-Jiménez, D. \& Sanz-Valle, R., 2011. Innovation, organizational learning, and performance. Journal of Business Research, 64(4), pp.408-417.

Jingmeng, M., 2013. A Study on Working Capital Management System based on Performance. International Journal of innovation, managment and Technology, 4(1), pp.100-103.

Kieschnick, R., LaPlante, M., \& Mousawwi, R., 2008. Working Capital Management, Corporate Governance, and Firm Value,

Kieschnick, R., Laplante, M. \& Moussawi, R., 2013. Working Capital Management and Shareholder Wealth. Review of Finance, 17(5), pp.1827-1852.

KPMG, 2011. Annual Working Capital Survey,

Lagat, C. \& Frankwick, G., 2015. Effect of market positioning on market orientation, innovation types and firm 
performance linkage. European Journal of Business and Management, 7(23), pp.193-205.

Lawrence, P. \& Lorsch, J., 1967. Organization and environment. Irwin: Homewood.

Lazaridis, I. \& Tryfonidis, D., 2006. “ The relationship between working capital management and profitability of listed companies in the Athens Stock Exchange ." Journal of Financial Management and Analysis, 30(76), pp.1-12.

Leavell, H., 2006. International working capital management. The Business Review, 5(1), p.233-239.

Li, C. et al., 2014. Working Capital Management, Corporate Performance, and Strategic Choices of the Wholesale and Retail Industry in China. The Scientific World Journal, 2014, pp.1-15.

Lifland, S., 2011. The Impact of Working Capital Efficiencies on the Enterprise Value Option: Empirical Analysis from the Energy Sector. Lifland Advances in Business Research, 2(1), pp.57-70.

Lind, L. et al., 2012. Working capital management in the automotive industry: Financial value chain analysis. Journal of Purchasing and Supply Management, 18(2), pp.92-100.

Lisboa, A., Skarmeas, D. \& Lages, C., 2011. Innovative capabilities: Their drivers and effects on current and future performance. Journal of Business Research, 64(11), pp.1157-1161.

Love, I., Preve, L.A. \& Sarria-Allende, V., 2007. Trade credit and bank credit: Evidence from recent financial crises. Journal of Financial Economics, 83(2), pp.453-469.

Love, I. \& Zaidi, R., 2010. Trade Credit, Bank Credit and Financial Crisis*. International Review of Finance, 10(1), pp.125-147.

Lyroudi, K. \& Lazaridis, J., 2000. The Cash Conversion Cycle and Liquidity Analysis. Social Science Research Network Electronic Paper Collection.

Mathuva, D.M., 2010. The Influence of Working Capital Management Components on Corporate Profitability: A Survey on Kenyan Listed Firms. Research Journal of Business Management, 4(1), pp.1-11.

Mohamad, N. \& Saad, N., 2010. Working Capital Management: The Effect of Market Valuation and Profitability in Malaysia. International Journal of Business and Management, 5(11), pp.140-147.

Nobanee, H., Abdullatif, M. \& AlHajjar, M., 2011. Cash conversion cycle and firm's performance of Japanese firms. Asian Review of Accounting, 19(2), pp.147-156.

Ortega, M.J.R., 2010. Competitive strategies and firm performance: Technological capabilities' moderating roles. Journal of Business Research, 63(12), pp.1273-1281.

Padachi, K., 2006. Trends in working capital management and its impact on firms' performance: an analysis of Mauritian small manufacturing firms. International Review of business research Papers, 2(2), pp.45-58.

Paul, S.Y. \& Boden, R., 2014. Trade Credit : A Literature Review. British Business Bank, (1-39).

Paul, S.Y., Devi, S.S. \& Teh, G.C., 2012. Impact of late payment on firm's profitability: Empirical evidence from Malaysia. Pacific-Basin Finance Journal, 20, pp.777-792. Peel, M.J., Wilson, N. \& Howorth, C., 2000. Late Payment and Credit Management in the Small Firm Sector: Some Empirical Evidence. International Small Business Journal, 18(2), pp.17-37.

Pomerleano, M., 1998. The East Asia Crisis and Corporate Finances. Working Paper, World Bank.

PWC, 2016. PWC Annual global WC survey-2016,

PWC, 2012. Working Capital: never been better -What the top performing companies are doing differently, 
Raheman, A. et al., 2010. Working capital management and corporate performance of manufacturing sector in Pakistan. ... Research Journal of ..., 47(47).

Raheman, A. \& Nasr, M., 2007. Working capital management and profitability-case of Pakistani firms. International review of business research ..., 3(1), pp.279-300.

REL, 2016. 2016 Europe Working Capital Survey,

Rhee, J., Park, T. \& Lee, D.H., 2010. Drivers of innovativeness and performance for innovative SMEs in South Korea: Mediation of learning orientation. Technovation, 30(1), pp.65-75.

Richards, V.D. \& Laughlin, E.J., 1980. A Cash Conversion Cycle Approach to Liquidity Analysis. Financial Management, 9(1), pp.32-38.

Rimo, A. \& Panbunyuen, P., 2010. The effect of company characteristics on working capital management.

Rydel. M. A, 2012. Improving Cash Flow Forecasting and Optimising Working Capital. www.gtnews.com, pp.2-3.

Samiloglu, F. \& Demirgunes, K., 2008. The Effect of Working Capital Management on Firm Profitability: Evidence from Turkey. The International Journal of Applied Economics and Finance, 2(1), pp.44-50.

Serrasqueiro, Z.S. \& MaçÃs Nunes, P., 2008. Performance and size: Empirical evidence from Portuguese SMEs. Small Business Economics, 31(2), pp.195-217.

Shin, H.H. \& Soenen, L., 1998. Efficiency of Working Capital and Corporate Profitability. Financial Practice and Education, , 8(2), pp.37-45.

Slaughter, C.L., 2015. Organizational Innovation $\hat{a}^{\mathrm{TM}} \mathrm{s}$ Moderation of Culture Effects on Company Financial Performance This is to certify that the doctoral dissertation by.

Soenen, L.A., 1993. Cash conversion cycle and corporate profitability. Journal of cash Management, (13), pp.53-53.

Subramanian, A. \& Nilakanta, S., 1996. Organizational innovativeness: exploring the relationship between organizational determinants of innovation, types of innovations, and measures of organizational performance. Omega, 24(6), pp.631-647.

Tauringana, V. \& Afrifa, G.A., 2013. The relative importance of working capital management and its components to SMEs' profitability. Journal of Small Business and Enterprise Development, 20(3), pp. $453-469$.

Terziovski, M., 2010. Innovation Practice and Its Performance Implications in Small and Medium Enterprises (SMEs) in the Manufacturing Sector: A resource based view. Strategic Management Journal, 31, pp.892902.

Tsai, K.H. \& Yang, S.Y., 2013. Firm innovativeness and business performance: The joint moderating effects of market turbulence and competition. Industrial Marketing Management, 42(8), pp.1279-1294.

Vuorikari, M., 2012. Optimizing Working Capital Management from Processes Perspective.

Walker, R.M., Chen, J. \& Aravind, D., 2015. Management innovation and firm performance: An integration of research findings. European Management Journal, 33(5), pp.407-422.

Wang, Y.-J., 2002. Liquidity management, operating performance, and corporate value: evidence from Japan and Taiwan. Journal of Multinational Financial Management, 12(2), pp.159-169.

Wasiuzzaman, S., 2015. Working capital and firm value in an emerging market. International Journal of Managerial Finance, 11(1), pp.60-79. 
Yam, R.C.M. et al., 2011. Analysis of sources of innovation, technological innovation capabilities, and performance: An empirical study of Hong Kong manufacturing industries. Research Policy, 40(3), pp.391-402.

Yang, J., 2012. Innovation capability and corporate growth: An empirical investigation in China. Journal of Engineering and Technology Management - JET-M, 29(1), pp.34-46.

Zainudin, N., 2008. Tracking the Credit Collection Period of Malaysian Small and Medium-Sized Enterprises. International Business Research, 1(1), pp.78-86.

ZHANG, J.A., GARRETT-JONES, S. \& SZETO, R., 2013. Innovation Capability and Market Performance: the Moderating Effect of Industry Dynamism. International Journal of Innovation Management, 17(2), p.1350004.

Zheng, Y., Liu, J. \& George, G., 2010. The dynamic impact of innovative capability and inter-firm network on firm valuation: A longitudinal study of biotechnology start-ups. Journal of Business Venturing, 25(6), pp.593-609. 